\title{
Plankton studies in Buzzards Bay, Massachusetts, USA. V. Ichthyoplankton, 1987 to 1993
}

\author{
Antonie S. Chute ${ }^{1}$, Jefferson T. Turner ${ }^{2, *}$ \\ ${ }^{1}$ National Oceanic and Atmospheric Administration, National Marine Fisheries Service, Northeast Fisheries Science Center, \\ 166 Water Street, Woods Hole, Massachusetts 02543, USA \\ ${ }^{2}$ Biology Department, University of Massachusetts Dartmouth, 285 Old Westport Road, North Dartmouth, \\ Massachusetts 02747, USA
}

\begin{abstract}
Monthly sampling for ichthyoplankton was conducted at 8 stations in Buzzards Bay, Massachusetts, from October 1987 to September 1993 using a $48 \mathrm{~cm}$ diameter plankton net with $0.102 \mathrm{~mm}$ mesh. From October 1992 to September 1993, an additional $75 \mathrm{~cm}$ diameter net with $0.202 \mathrm{~mm}$ mesh was also towed to compare mesh selectivity. Stations included two with heavy anthropogenic impact, the urbanized inner harbor of New Bedford, Massachusetts, and over New Bedford's offshore sewage outfall, as well as other nearshore shallow and offshore deep stations in comparatively pristine areas of the bay. Fish larvae from 32 genera were identified. Fish eggs were counted but not identified. There was a pronounced summer peak in larval abundance dominated by cunner Tautogolabrus adspersus, anchovy Anchoa sp. and tautog Tautoga onitis. A smaller winter/ early spring peak was dominated by sand lance Ammodytes sp. This pattern was evident for all 6 years of the study. The assemblage of fish larvae found in Buzzards Bay differed from that in Cape Cod Bay, lending support to the concept of Cape Cod as a faunal boundary. The 2 differently sized nets used during the last year of the study did not catch significantly different numbers of fish larvae per $\mathrm{m}^{3}$, but length frequency distributions of 4 abundant species of larvae revealed that the smaller mesh net caught significantly smaller Anchoa sp. The larger mesh net collected significantly more species of fish larvae. A comparison of annual mean catches of 4 species did not reveal significant changes in abundance over 6 yr.
\end{abstract}

KEY WORDS: Ichthyoplankton · Composition · Abundance $\cdot$ Buzzards Bay

\section{INTRODUCTION}

Many marine fishes, including those that are not resident species, spawn in or near productive coastal bays and estuaries (Wheatland 1956, Richards 1959, Pearcy \& Richards 1962, Powles et al. 1984). Hydrographic conditions that retain planktonic eggs and larvae within bays and estuaries (Doyle et al. 1993), together with enhanced densities of food, may allow developing larvae to grow rapidly into strong swimmers, thus helping them to avoid predators and resist being dispersed by currents (Bourne \& Govoni 1988, Olney \& Boehlert 1988).

\footnotetext{
*Corresponding author. E-mail: jturner@umassd.edu
}

Ichthyoplankton species composition and abundance data can help elucidate local patterns of distribution and spawning for non-resident as well as local species, and determine an area's importance as a nursery ground. Ichthyoplankton data can also help clarify broad-scale trends of fish distribution and spawning ranges; such an area of interest is located around Cape Cod, which has long been considered a faunal boundary (Ekman 1953, Anraku 1964, Scherer 1984, Azarovitz \& Grosslein 1987). The narrow peninsula of Cape Cod divides Cape Cod Bay, which is influenced by cold Gulf of Maine water, from Buzzards Bay, which is influenced by warmer Mid-Atlantic Bight water (Collings et al. 1981). The $11 \mathrm{~km}$ long Cape Cod Canal connects Buzzards Bay and Cape Cod Bay (Fig. 1). 


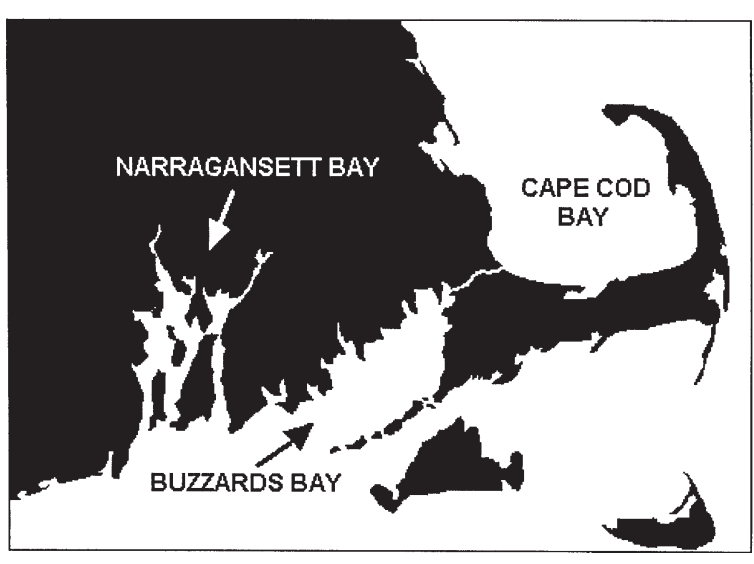

Fig. 1. Location of Buzzards Bay in relation to Narragansett Bay and Cape Cod Bay

Thus, Buzzards Bay is a mixture of 2 very different water masses, particularly at its northern end. The proximity and connectedness of the 2 bays prompts a comparison of ichthyoplankton assemblages.

Buzzards Bay is a large embayment (45 km long and an average of $13 \mathrm{~km}$ wide), and because of an average depth of only $11 \mathrm{~m}$, the bay remains well mixed by wind and tide throughout the year, and undergoes large annual fluctuations in temperature (Turner \& Borkman 1993). Semidiurnal tidal flow floods northeast into and ebbs southwest out of the bay through its entrance at the south end, and through the channels in the Elizabeth Islands along the southern boundary of the bay.

Buzzards Bay can be characterized as 'partially urbanized' (Turner \& Borkman 1993) with numerous point sources of pollution, such as municipal wastewater treatment facilities. Buzzards Bay has been classified by NOAA/EPA (1989) as highly susceptible to concentrating pollutants due to large overall volume relative to comparatively low volume of freshwater inflow that would flush the estuary. These same characteristics would facilitate retention of ichthyoplankton within the bay.

The primary objective of this study was to determine annual patterns and interannual variability of ichthyoplankton distributions in Buzzards Bay, and to relate these patterns to those reported for adjacent estuarine areas to the north and south, in order to clarify the biogeographical position of Buzzards Bay along a distributional gradient of fish species. Several ichthyoplankton surveys have been conducted in adjacent southern New England coastal waters, including Cape Cod Bay (Scherer 1984), Narragansett Bay (Herman 1963, Bourne \& Govoni 1988, Keller et al. 1999), Block Island Sound (Merriman \& Sclar 1952) and Long Island Sound (Wheatland 1956, Monteleone et al. 1987). A secon- dary objective was to compare ichthyoplankton in anthropogenically impacted versus more pristine areas of the bay. Although there have been several ichthyoplankton surveys in the Buzzards Bay region, presented in reports of management agencies or unpublished theses (Lebida 1969, Stolgitis 1970, Crestin 1973, Govoni 1973, Collings et al. 1981, Lux \& Wheeler 1992), these were for only part of the year, or for portions of the bay or its tributaries. There has never been a multi-year qualitative and quantitative ichthyoplankton survey in the open waters of Buzzards Bay.

\section{MATERIALS AND METHODS}

Samples were collected over a span of $6 \mathrm{yr}$, from October 1987 to September 1993. There were a total of 17 cruises in the first year (October 1987 and June through October 1988 sampled biweekly, the rest of the year sampled monthly) and 16 in the second year (June through August 1989 sampled biweekly, the rest of the year sampled monthly). A monthly sampling schedule followed for the remaining $4 \mathrm{yr}$ of the study. A total of 484 samples from 81 cruises were analyzed. Each cruise sampled at 8 stations around the bay (Fig. 2). Five stations were situated on the periphery of the bay, including the southern entrance to the Cape Cod Canal (Stn 2) and the New Bedford sewage outfall site (Stn 7), and 3 stations in the open water areas of the bay (Stns 4, 5 and 6). All stations were between 5 and $15 \mathrm{~m}$ deep, the mid-bay stations being the deepest.

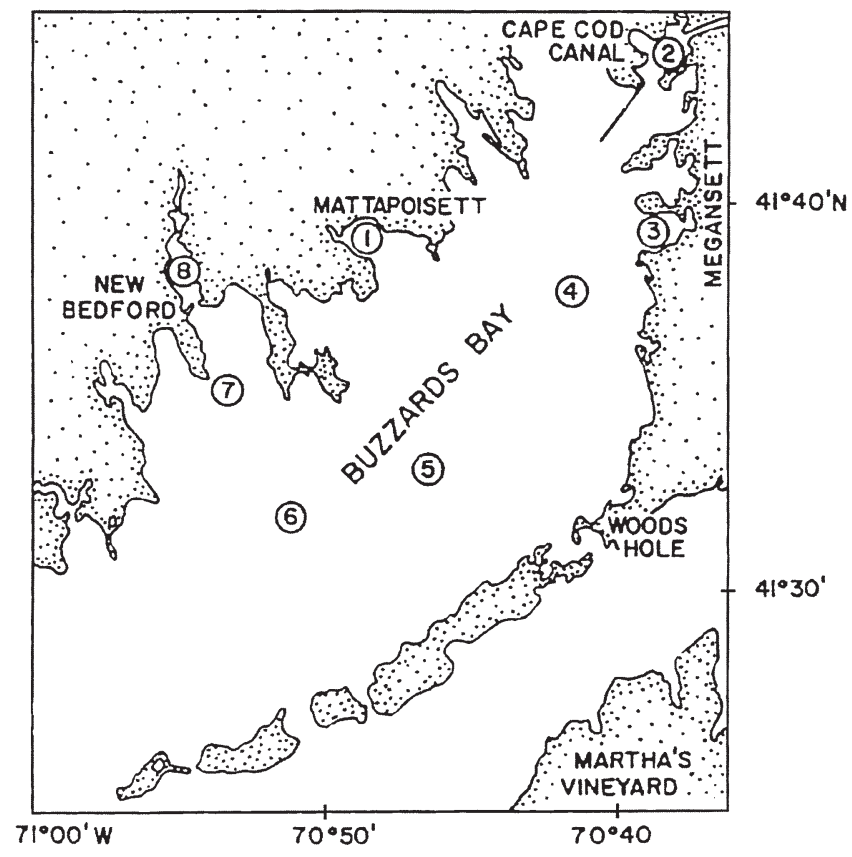

Fig. 2. Sampling stations in Buzzards Bay 
Stations were located using Loran coordinates. Cruises were always completed in a single day. All samples were taken during daylight hours, and stations were sampled upon arrival, irrespective of tidal state.

The sampling protocol used for the first $5 \mathrm{yr}$ of this study was originally designed for zooplankton. Such a protocol has been proven effective for collecting fish larvae (Olney 1983), even though zooplankton tow times are shorter, and net meshes and diameters are generally smaller than those typically used in ichthyoplankton surveys. A double oblique net tow (down and up) was made at each station, from the surface to approximately $1 \mathrm{~m}$ above the bottom (judged by wire out and wire angle) with a $48 \mathrm{~cm}$ diameter $0.102 \mathrm{~mm}$ mesh zooplankton net equipped with a flowmeter and closed cod end jar. When sampling with a $0.102 \mathrm{~mm}$ mesh net in phytoplankton rich estuarine waters, net clogging can occur during periods of blooms of chainforming diatoms. Care was taken to ensure that flowmeters were still turning upon retrieval of the nets, indicating no clogging. When clogging occurred, samples were discarded and tows were repeated for shorter time intervals, until tows without clogging were obtained. Samples were preserved within minutes in 5\% formaldehyde, and after at least $3 \mathrm{wk}$ curing time, samples were transferred to $70 \%$ ethanol solutions. Upon arrival at each station, surface, middepth and bottom water temperatures were recorded using an electronic temperature probe. Salinities were measured with a refractometer from surface, middepth and bottom Niskin bottle samples.

Two plankton nets were towed consecutively at each station for the final year of sampling: the aforementioned $0.102 \mathrm{~mm}$ mesh net and a $0.202 \mathrm{~mm}$ mesh net with a $75 \mathrm{~cm}$ mouth diameter. Double oblique tows were made with each net, one immediately after the other, and the same preservation procedure was followed for both tows. Tows made with the $0.202 \mathrm{~mm}$ mesh net averaged about $50 \mathrm{~s}$ and filtered an average of $10.4 \mathrm{~m}^{3}$ of water $(\mathrm{n}=96)$. Tows made with the $0.102 \mathrm{~mm}$ mesh net averaged $52 \mathrm{~s}$ and filtered an average of $5.3 \mathrm{~m}^{3}$ of water $(\mathrm{n}=388)$.

Table 1. Average lengths are based on fish collected during the entire 6 yr sampling period; the total number of larvae collected was 7871

\begin{tabular}{|c|c|c|c|}
\hline Species & Common name & Total no. & Average length in mm (range) \\
\hline Tautogolabrus adspersus & Cunner & 2942 & $2.9(1.0-11.5)$ \\
\hline Anchoa sp. & Anchovy & 2228 & $2.8(1.4-15.4)$ \\
\hline Tautoga onitis & Tautog & 922 & $3.1(1.0-8.5)$ \\
\hline Ammodytes sp. & Sand lance & 706 & $7.5(3.6-25.0)$ \\
\hline Stenotomus chrysops & Scup & 404 & $2.7(1.3-7.6)$ \\
\hline Peprilus triacanthus & Butterfish & 93 & $2.5(1.5-8.5)$ \\
\hline Etropus microstomus & Smallmouth flounder & 91 & $3.2(1.2-10.9)$ \\
\hline Pleuronectes americanus & Winter flounder & 84 & $3.5(2.2-7.2)$ \\
\hline Centropristis striata & Black sea bass & 51 & $2.3(1.2-4.5)$ \\
\hline Gobiosoma sp. & Goby & 46 & $2.8(2.1-5.0)$ \\
\hline Myoxocephalus sp. & Sculpin & 45 & $7.5(5.0-15.0)$ \\
\hline Prionotus sp. & Sea robin & 38 & $2.7(1.6-9.0)$ \\
\hline Enchelyopus cimbrius & Fourbeard rockling & 36 & $3.5(2.0-8.0)$ \\
\hline Paralichthys oblongus & Fourspot flounder & 25 & $3.2(2.0-5.6)$ \\
\hline Scophthalmus aquosus & Windowpane & 22 & $3.0(1.8-7.6)$ \\
\hline Trinectes maculatus & Hogchoker & 17 & $2.1(1.7-3.7)$ \\
\hline Syngnathus fuscus & Northern pipefish & 16 & $21.0(9.0-25.0)$ \\
\hline Scomber scombrus & Atlantic mackerel & 15 & $4.1(1.3-10.0)$ \\
\hline Pholis gunnellus & Rock gunnel & 12 & $13.1(10.5-19.0)$ \\
\hline Brevoortia tyrannus & Atlantic menhaden & 9 & $4.0(2.2-7.5)$ \\
\hline Menidia menidia & Atlantic silverside & 6 & $6.6(4.4-9.0)$ \\
\hline Cryptacanthodes maculatus & Wrymouth & 5 & $28.6(25.0-33.0)$ \\
\hline Liparis atlanticus & Sea snail & 4 & $3.4(2.9-4.1)$ \\
\hline Urophysis sp. & Hake & 4 & $2.3(1.8-3.0)$ \\
\hline Ulvaria subbifurcata & Radiated shanny & 3 & $6.6(5.4-8.0)$ \\
\hline Ophidion marginatum & Margined cusk eel & 3 & $4.9(3.0-8.5)$ \\
\hline Urophysis chuss & Red hake & 2 & $7.3(6.8-7.7)$ \\
\hline Merluccius bilinearis & Silver hake & 2 & $2.9(2.8-2.9)$ \\
\hline Clupea harengus & Atlantic herring & 2 & $17.25(12.5-22.0)$ \\
\hline Paralichthys dentatus & Summer flounder & 1 & 6.0 \\
\hline Glyptocephalus cynoglossus & Witch flounder & 1 & 5.3 \\
\hline Cynoscion regalis & Weakfish & 1 & 1.8 \\
\hline Unidentifiable & & 35 & \\
\hline
\end{tabular}




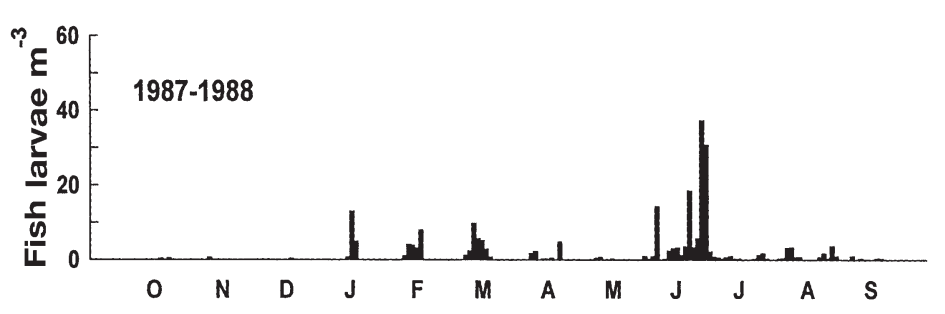

Fig. 3. Densities of fish larvae $\left(\mathrm{n} \mathrm{m}^{-3}\right)$ collected at each station in 1987 to 1988. Unlabelled histograms represent densities at (in order) Stns 1 to 8. Sampling was conducted twice during the months of October 1987, and June, July, August and September 1988. In the figure there are 2 groups of histograms for these months, one for the first sampling cruise of the month, and another for the second

Fish eggs and larvae were sorted from the samples using a dissecting microscope, and fish larvae were identified to the lowest possible taxon and measured to the nearest $0.1 \mathrm{~mm}$ total length with an ocular micrometer. Preserved lengths were transformed using Theilacker's (1980) equation to better approximate live lengths. Fish eggs were counted (total $=17520$ ) but not

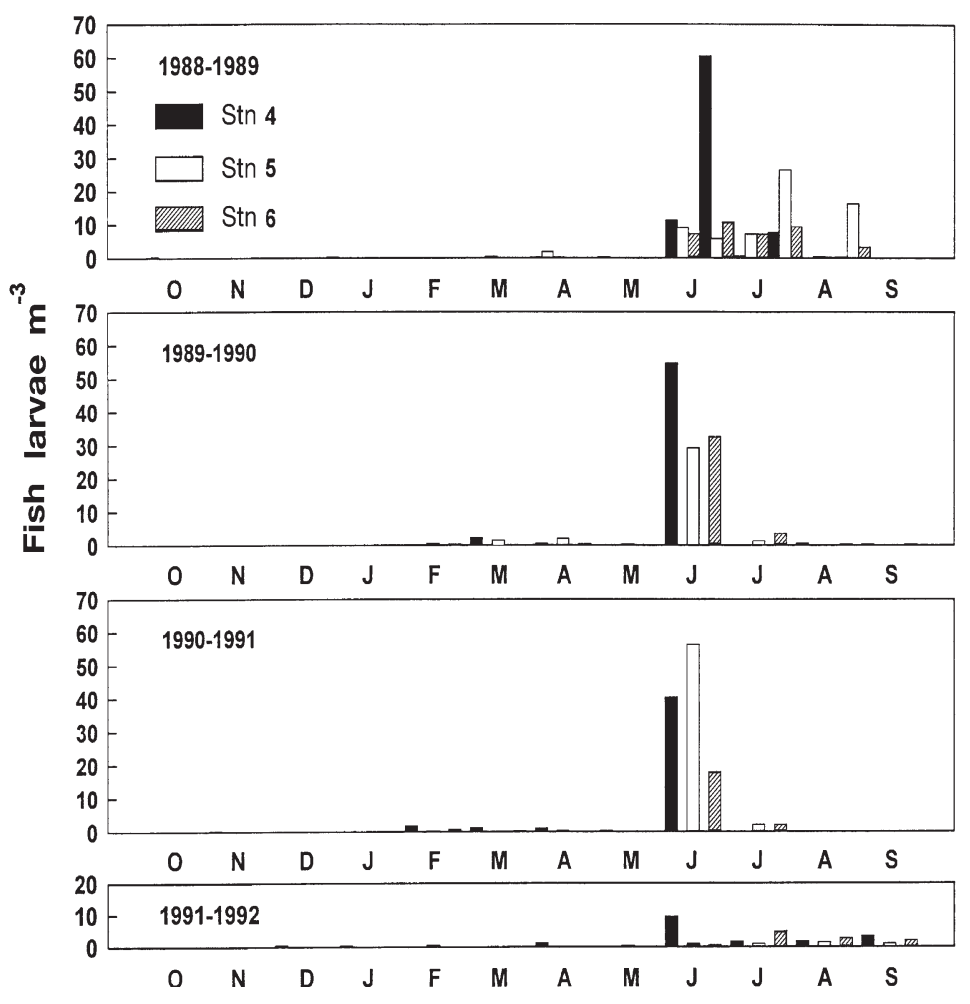

Fig. 4. Densities of fish larvae $\left(\mathrm{n} \mathrm{m}^{-3}\right)$ collected at Stns 4, 5 and 6 during the middle years of the study, 1988-1989, 1989-1990, 1990-1991 and 1991-1992. Sampling was conducted twice during the months of October 1987, and June, July, August and September 1988. In the figure there are 2 groups of histograms for these months, one for the first sampling cruise of the month, and another for the second identified. For the first and last years of the study (October 1987 through September 1988, and October 1992 through September 1993), ichthyoplankton samples from all 8 stations were sorted. For the middle $4 \mathrm{yr}$ (October 1988 through September 1992) only samples from the open water stations (Stns 4, 5 and 6) were analyzed.

To test whether the $0.75 \mathrm{~m}$ diameter net with the $0.202 \mathrm{~mm}$ mesh was a more efficient sampler of fish larvae than the $0.5 \mathrm{~m}$ diameter net with the $0.102 \mathrm{~mm}$ mesh, numbers of fish larvae (expressed as larvae per $\mathrm{m}^{3}$ of water filtered) caught by both nets were compared using a Wilcoxon matched-pairs test. To investigate whether the nets were sampling the same sizes of fish, a nonparametric KolmogorovSmirnov 2-sample test was performed on untransformed length frequency data for the 4 most abundant species caught by both nets.

A $t$-test was also performed on $\log (x+1)$ transformed data. The Kolmogorov-Smirnov test detects differences in the distributions of the 2 samples of fish lengths, while the $t$-test tests for differences in the means.

\section{RESULTS}

Twenty-six species of fish larvae were identified (Table 1), and additional taxa were identified only to genus due to uncertain taxonomy (Ammodytes; Nizinski et al. 1990) or difficulty in separating species due to small size of specimens (Anchoa, Gobiosoma, Prionotus, Myoxocephalus).

The labrid fishes Tautogolabrus adspersus (cunner) and Tautoga onitis (tautog) comprised nearly half of the total collection of 7871 larvae, with 38 and $11 \%$ respectively (Table 1 ). The forage fishes Anchoa sp. (anchovies) and Ammodytes sp. (sand lance) represented a total of $38 \%$ of the catch, with $9 \%$ sand lance and $29 \%$ anchovy. The fifth most abundant larvae were Stenotomus chrysops (scup), consisting of $5 \%$ of the total. Peprilus triacanthus (butterfish), Etropus microstomus (smallmouth flounder), and Pleuronectes americanus (winter flounder) made up $1 \%$ each. The remaining 23 species and generic groups comprised a combined total of only $5 \%$ of the catch. Individuals of several species were found $<10$ times, and 4 species were represented by a single specimen only. This pattern of dominance by a few species is a common one (Chenoweth 
1973, Olney 1983, Bourne \& Govoni 1988, Monteleone 1992).

Fish larvae were collected during every month of the year (Table 2 ), in a repeated annual pattern (Figs 3, 4 \& 5). Samples collected during the months of October, November and December contained very few larvae. In January, an increase in spawning activity was evidenced by catches of Ammodytes sp., Myoxocephalus sp. and Pleuronectes americanus larvae, which continued through April. Since these species hatch from demersal eggs, the eggs collected at this time (usually less than $2 \mathrm{~m}^{-3}$ ) may have been stirred up from the bottom.

Peak abundance of fish eggs (Figs 6 \& 7) and larvae occurred during June, July and August of every year. During these months, Anchoa sp. and Tautogolabrus adspersus were the most abundant larvae in the samples. Anchoa sp. and Tautoga onitis had extended spawning periods starting in June, peaking in July and

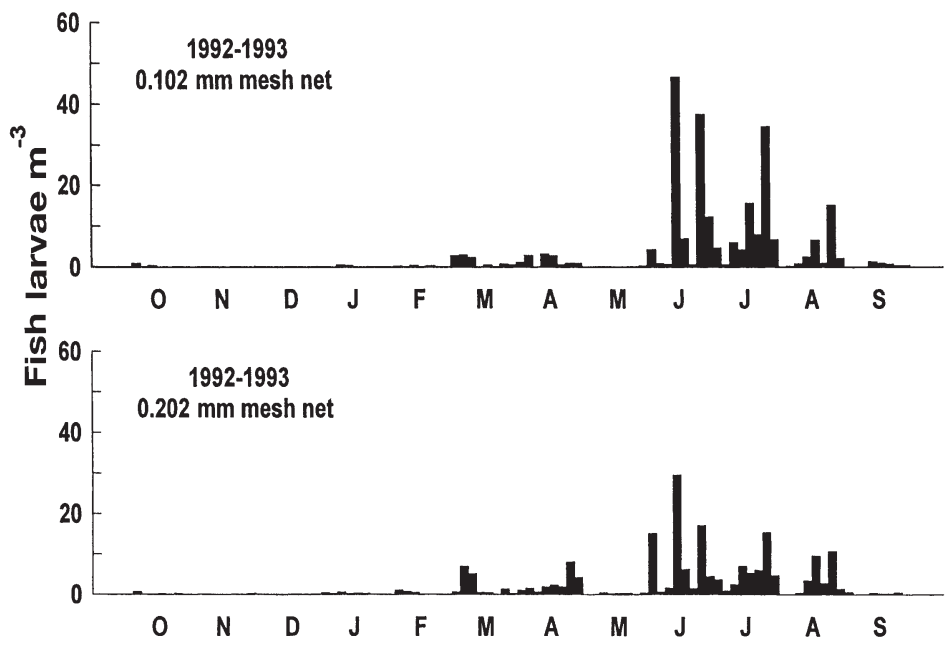

Fig. 5. Densities of fish larvae $\left(\mathrm{n} \mathrm{m}^{-3}\right)$ collected at each station in 1992 to 1993 with the $0.102 \mathrm{~mm}$ mesh net (upper) and the $0.202 \mathrm{~mm}$ mesh net (lower). Unlabelled histograms represent densities at (in order) Stns 1 to 8

Table 2. Species of larval fish collected in Buzzards Bay from October 1987 through October 1993. Months during which a species was collected are indicated by $\mathrm{x}$

\begin{tabular}{|c|c|c|c|c|c|c|c|c|c|c|c|c|}
\hline Species & $\mathrm{J}$ & $\mathrm{F}$ & M & A & $\mathrm{M}$ & $\mathrm{J}$ & $\mathrm{J}$ & A & $\mathrm{S}$ & $\mathrm{O}$ & $\mathrm{N}$ & $\mathrm{D}$ \\
\hline Ammodytes sp. & $\mathrm{x}$ & $\mathrm{x}$ & $\mathrm{x}$ & $\mathrm{x}$ & $\mathrm{x}$ & & & & & & & $\mathrm{x}$ \\
\hline Mуохосерhalus sp. & $\mathrm{x}$ & $\mathrm{x}$ & $\mathrm{x}$ & $\mathrm{x}$ & $\mathrm{x}$ & & & & & & & \\
\hline Pholis gunnellus & $\mathrm{x}$ & $\mathrm{x}$ & $\mathrm{x}$ & & & & & & & & & \\
\hline Pleuronectes americanus & & & & $\mathrm{x}$ & $\mathrm{x}$ & $\mathrm{x}$ & & & & & & \\
\hline Enchelyopus cimbrius & & & & $\mathrm{x}$ & $\mathrm{x}$ & $\mathrm{x}$ & $\mathrm{x}$ & & $\mathrm{x}$ & $\mathrm{x}$ & & \\
\hline Cryptacanthodes maculatus & & & & $\mathrm{x}$ & & & & & & & & \\
\hline Glyptocephalus cynoglossus & & & & $\mathrm{x}$ & & & & & & & & \\
\hline Centropristis striata & & & & & $\mathrm{x}$ & $\mathrm{x}$ & $\mathrm{x}$ & $\mathrm{x}$ & & & & \\
\hline Liparis atlanticus & & & & & $\mathrm{x}$ & & & & & & & \\
\hline Ulvaria subbifurcata & & & & & $\mathrm{x}$ & & & & & & & \\
\hline Tautogolabrus adspersus & & & & & & $\mathrm{x}$ & $\mathrm{x}$ & $\mathrm{x}$ & & & & \\
\hline Anchoa sp. & & & & & & $\mathrm{x}$ & $\mathrm{x}$ & $\mathrm{x}$ & $\mathrm{x}$ & & & \\
\hline Tautoga onitis & & & & & $\mathrm{x}$ & $\mathrm{x}$ & $\mathrm{x}$ & $\mathrm{x}$ & & & & \\
\hline Stenotomus chrysops & & & & & & $\mathrm{x}$ & $\mathrm{x}$ & $\mathrm{x}$ & & & & \\
\hline Peprilus triacanthus & & & & & & $\mathrm{x}$ & $\mathrm{x}$ & $\mathrm{x}$ & & & & \\
\hline Etropus microstomus & & & & & & $\mathrm{x}$ & $\mathrm{x}$ & $\mathrm{x}$ & $\mathrm{x}$ & $\mathrm{x}$ & & \\
\hline Gobiosoma sp. & & & & & & $\mathrm{x}$ & $\mathrm{x}$ & $\mathrm{x}$ & $\mathrm{x}$ & & & \\
\hline Prionotus sp. & & & & & & $\mathrm{x}$ & $\mathrm{x}$ & $\mathrm{x}$ & $\mathrm{x}$ & & & \\
\hline Paralichthys oblongus & & & & & & $\mathrm{x}$ & $\mathrm{x}$ & $\mathrm{x}$ & & & & \\
\hline Scopthalmus aquosus & & & & & & $\mathrm{x}$ & $\mathrm{x}$ & & $\mathrm{x}$ & $\mathrm{x}$ & & \\
\hline Trinectes maculatus & & & & & & $\mathrm{x}$ & $\mathrm{x}$ & $\mathrm{x}$ & & & & \\
\hline Sygnathus fuscus & & & & & & $\mathrm{x}$ & $\mathrm{x}$ & $\mathrm{x}$ & $\mathrm{x}$ & & & \\
\hline Scomber scombrus & & & & & & $\mathrm{x}$ & $\mathrm{x}$ & & & & & \\
\hline Brevoortia tyrannus & & & & & & $\mathrm{x}$ & & & & & $\mathrm{x}$ & \\
\hline Menidia menidia & & & & & & $\mathrm{x}$ & $\mathrm{x}$ & & & & & \\
\hline Urophysis sp. & & & & & & & $\mathrm{x}$ & & $\mathrm{x}$ & $\mathrm{x}$ & & \\
\hline Ophidion marginatum & & & & & & & $\mathrm{x}$ & $\mathrm{x}$ & $\mathrm{x}$ & & & \\
\hline Cynoscion regalis & & & & & & & $\mathrm{x}$ & & & & & \\
\hline Merluccius bilinearis & & & & & & & & & & $\mathrm{x}$ & & \\
\hline Clupea harengus & & & & & & & & & & & $\mathrm{x}$ & $\mathrm{x}$ \\
\hline Paralichthys dentatus & & & & & & & & & & & $\mathrm{x}$ & \\
\hline
\end{tabular}




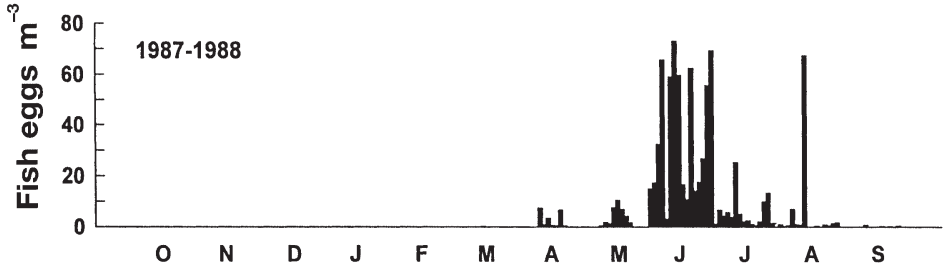

Fig. 6. Densities of fish eggs $\left(\mathrm{n} \mathrm{m}^{-3}\right)$ collected at each station in 1987 to 1988. Unlabelled histograms represent densities at (in order) Stns 1 to 8 . Sampling was conducted twice during the months of October 1987, and June, July, August and September 1988. In the figure there are 2 groups of histograms for these months, one for the first sampling cruise of the month, and another for the second highest densities of fish larvae were found at Stn 7, over the outfall from the New Bedford wastewater treatment facility. Borkman \& Turner (1993) and Pierce \& Turner $(1994 a, b)$ also found the highest abundances of phytoplankton, tintinnids and dinoflagellates at this station compared to the others in Buzzards Bay. With the constant input of nutrients, the sewage outfall station provided an abundant source of food for both the larval fish and spawning adults, and perhaps a refuge from visual predators, since the water was quite turbid. The stations at the edges of the bay (Stns 1, 3, 7 and 8) contributed the most larvae to the late winter/early spring pulse. During the middle 4 yr of the study when only the open water stations were analyzed, the pattern of 2 annual larval peaks was not as pronounced. This was expected, since many estuarine species spawn in the winter (de Lafontaine 1990), and since our stations at the periphery of the bay were closer to marshes and rivers, larvae originating further up the estuary would be collected there. Stn 2 (the entrance to the Cape Cod Canal) was similar to these more estuarine stations in that it had a late winter/early spring pulse of eggs and lacked the large summer peak. The larval fish assemblage collected at Stn 2 in the Cape Cod Canal was also unique (Table 3). As the tide ebbs, Cape Cod Bay water floods into the canal and brings with it the distinctly different assemblage of plankton found north of Cape Cod. Since Stn 2 was a hybrid of Cape Cod Bay water and Buzzards Bay water, it had an intermediate ichthyoplankton assemblage which lacked the distinctive large summer peaks of the more southern Anchoa sp. and Tautoga onitis.

Comparisons of sampling by the 2 types of nets produced interesting results. There was no significant dif-

early August, and continuing until September. T. adspersus, although more abundant than $T$. onitis, apparently had a shorter spawning period since no cunner larvae were collected after August in any year. Other larvae found consistently in June, July and August included those of Stenotomus chrysops, Etropus microstomus, Peprilus triacanthus and Centropristis striata (black sea bass). Most of the summer spawners, such as T. adspersus, T. onitis and Anchoa sp. have pelagic rather than demersal eggs. This was reflected in the increased numbers of fish eggs collected in June and July.

For the years during which samples from all 8 stations were analyzed, areal trends were apparent. The largest numbers and

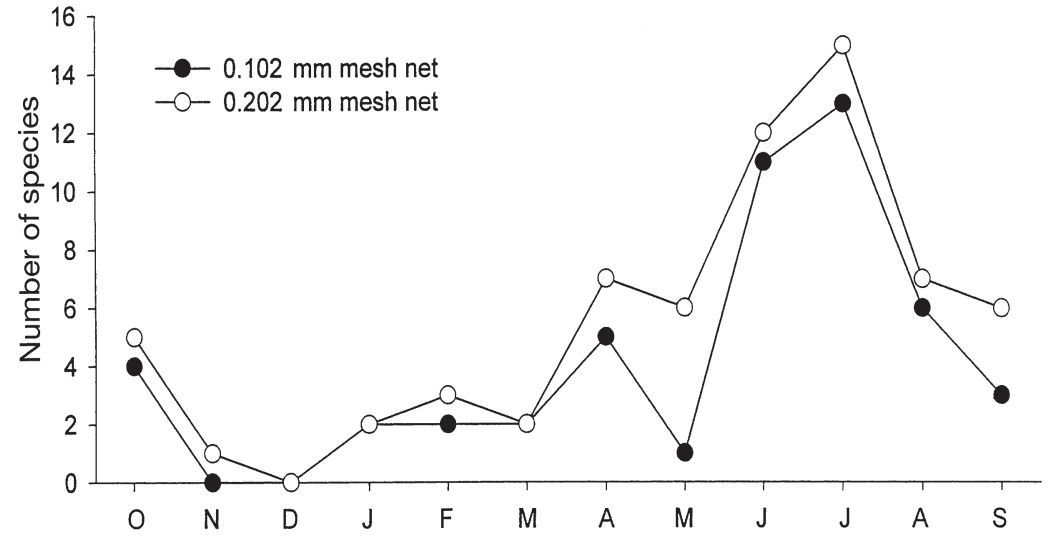

Fig. 8. Number of species of fish larvae collected per month over the 1992 to 1993 sampling year, from both the 0.102 and $0.202 \mathrm{~mm}$ mesh nets 
ference in total numbers of larvae $\mathrm{m}^{-3}$ caught by the 2 nets ( $\mathrm{p}=0.839124, \mathrm{n}=67$ pairs). Further, length frequency distributions of the most abundant taxa revealed that for Ammodytes sp., Tautogolabrus adspersus and Tautoga onitis the results of the Kolmogorov-Smirnov test were not significant $(p=0.1772$, $\mathrm{n}=362 ; \mathrm{p}=0.2385, \mathrm{n}=1056 ;$ and $\mathrm{p}=0.5053, \mathrm{n}=307$ respectively), indicating that the nets were not catching different sizes of larvae. For Anchoa sp., however, the Kolmogorov-Smirnov results were significantly different ( $p=0.0001, n=1256)$, indicating the nets sampled 2 different size distributions of anchovy larvae. The results of the $t$-test show a significant difference in mean sizes of Anchoa sp. ( $p=0.0001$, mean $0.102 \mathrm{~mm}$ = 3.55, mean $0.202 \mathrm{~mm}=3.97$ ) and in Ammodytes sp. $(\mathrm{p}=0.0252$, mean $0.102 \mathrm{~mm}=9.57$, mean $0.202 \mathrm{~mm}=$ 10.50) for the 2 nets. In both cases, the larger mesh net was catching the larger larvae. T. onitis and T. adspersus were not found to have significantly different mean lengths $(p=0.7609$, mean $0.102 \mathrm{~mm}=3.53$, mean $0.202 \mathrm{~mm}=3.60 ; \mathrm{p}=0.1219$, mean $0.102 \mathrm{~mm}=3.22$, mean $0.202 \mathrm{~mm}=3.36$ respectively). There was also a significantly higher number of species taken per station with the larger (0.202 mm mesh) net (Fig. 8) over the full year when all 8 stations were sampled with both nets (Wilcoxon 2-sample test, $\mathrm{p}=0.0059, \mathrm{n}=16$ ).

\section{DISCUSSION}

The species assemblage of fish larvae collected in Buzzards Bay was qualitatively different from that reported for Cape Cod Bay, despite the physical connection provided by the Cape Cod Canal. Scherer's (1984) study of the ichthyoplankton of Cape Cod Bay from 1974 to 1976 found Ammodytes sp. to be the most abundant fish larva in Cape Cod Bay, followed by Enchelyopus cimbrius, Scomber scombrus, Urophycis sp. and Tautogolabrus adspersus (Table 3). In contrast, the present study found Buzzards Bay to be dominated by T. adspersus, with Ammodytes sp. ranked fourth and E. cimbrius, S. scombrus and Urophycis sp. represented in very few collections. Anchoa sp. and Tautoga onitis, the second and third most abundant species in Buzzards Bay, were ranked 29th and 22nd, respectively, in Scherer's study. Stenotomus chrysops (scup), Centropristis striata (black sea bass) and Etropus microstomus (smallmouth flounder), all of which made consistent albeit modest contributions to the Buzzards Bay larvae, were considered by Scherer to be 'stragglers from the south' when found above Cape Cod.

Narragansett Bay, Rhode Island (Fig. 1), sampled extensively in 1972 to 1973 (Bourne \& Govoni 1988) and again in 1989 to 1990 (Keller et al. 1999), has a larval fish assemblage similar to Buzzards Bay. In both
Table 3. Species of fish larvae listed in descending order of abundance for Cape Cod Bay from 1974 to 1976 (Scherer 1984), Stn 2 at the southern end of the Cape Cod Canal from 1987 to 1988, and 1992 to 1993 (present study), all stations in Buzzards Bay from 1987 to 1993 (present study), Buzzards Bay from 1976 to 1979 (Collings et al. 1981) and Narragansett Bay from 1989 to 1990 (Keller et al. 1999). Numbers in parentheses are the maximum densities (larvae $\mathrm{m}^{-3}$ ) collected during the study

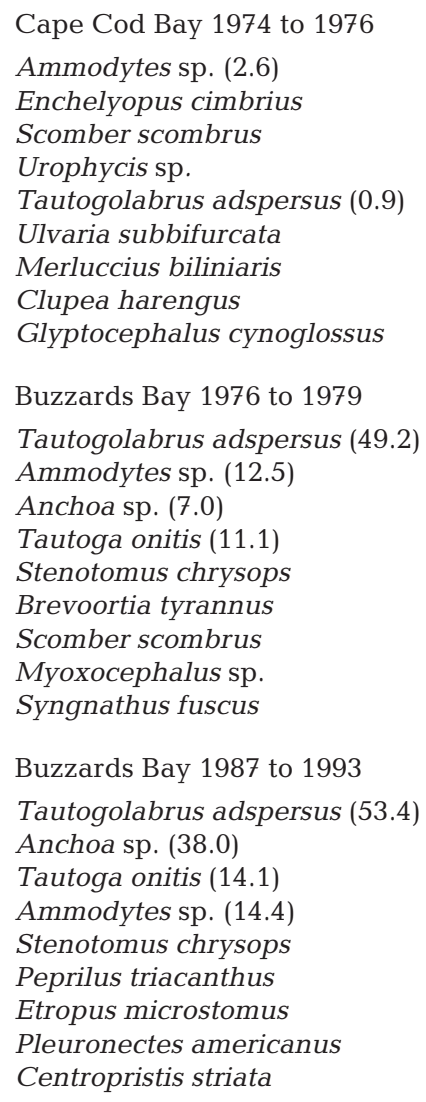

Buzzards Bay 1976 to 1979

Tautogolabrus adspersus (49.2)

Ammodytes sp. (12.5)

Anchoa sp. (7.0)

Tautoga onitis (11.1)

Stenotomus chrysops

Brevoortia tyrannus

Scomber scombrus

Myoxocephalus sp.

Syngnathus fuscus

Buzzards Bay 1987 to 1993

Tautogolabrus adspersus (53.4)

Anchoa sp. (38.0)

Tautoga onitis (14.1)

Ammodytes sp. (14.4)

Stenotomus chrysops

Peprilus triacanthus

Etropus microstomus

Pleuronectes americanus

Centropristis striata

Cape Cod Canal Stn 21987 to 1988, 1992 to 1993

Ammodytes sp. (6.7)

Pleuronectes americanus

Tautogolabrus adspersus (1.1)

Enchelyopus cimbrius

Anchoa sp. (0.3)

Myoxocephalus sp.

Tautoga onitis (0.4)

Pholis gunellus

Scomber scombrus

Narragansett Bay 1989 to 1990

Anchoa sp. (26.5)

Tautoga onitis (2.7)

Tautogolabrus adspersus (3.6)

Pleuronectes americanus

Gobiosoma ginsbergi

Brevoortia tyrannus

Scophthalmus aquosus

Peprilus triacanthus

Paralichthys oblongus 

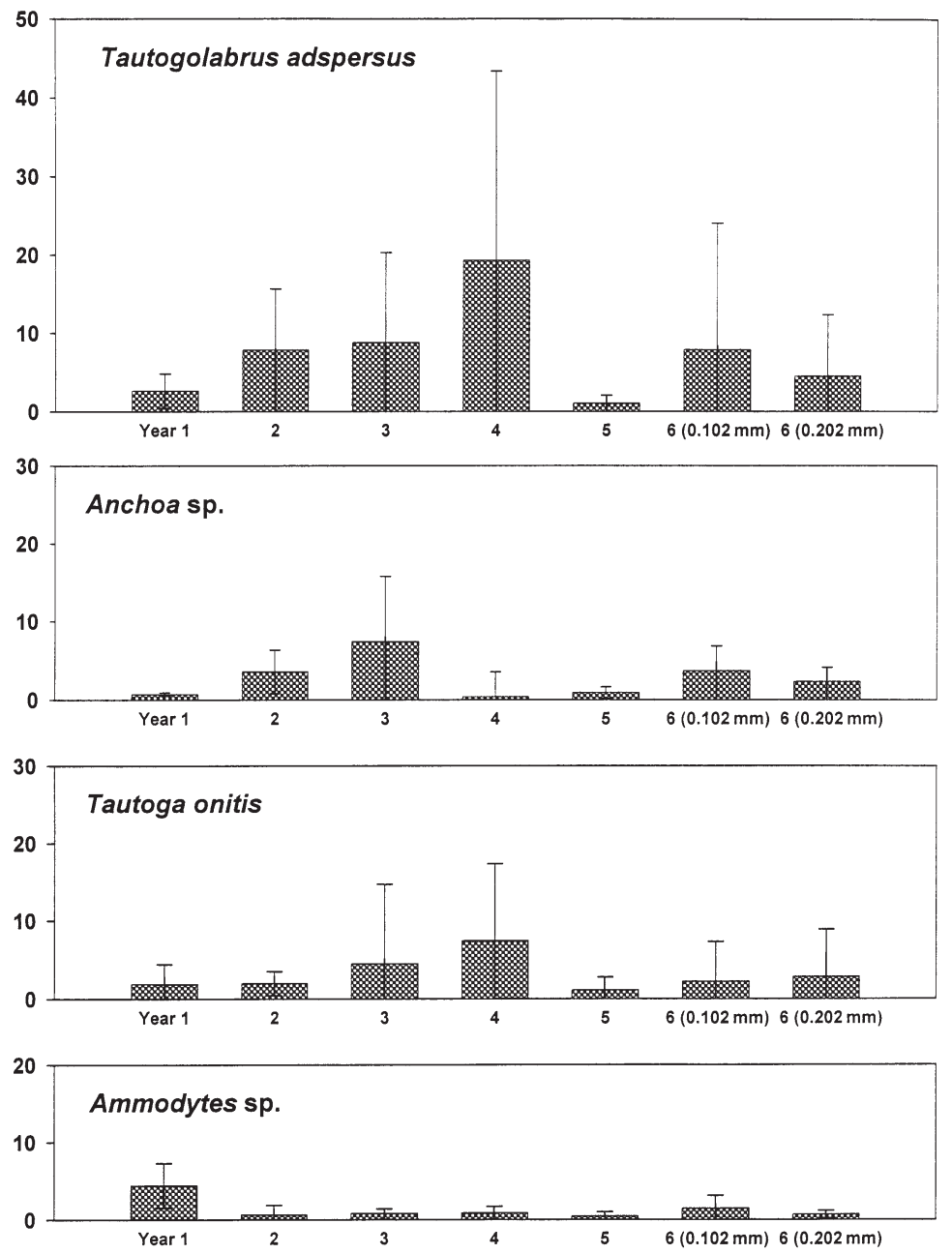

Fig. 9. Mean annual densities of fish larvae $\left(\mathrm{n} \mathrm{m}^{-3}\right)$ for the 4 most abundant species (Tautogolabrus adspersus, Anchoa sp., Tautoga onitis, Ammodytes sp.) taken at mid-bay Stns 4, 5 and 6 during the $6 \mathrm{yr}$ of the study from all $0.102 \mathrm{~mm}$ mesh net samples where they occurred. Year 6 shows data from the 0.102 and $0.202 \mathrm{~mm}$ mesh nets. Histograms are means and vertical error bars are 95\% confidence limits. Year 1 is 1987 to 1988, Year 2 is 1988 to 1989, Year 3 is 1989 to 1990, Year 4 is 1990 to 1991, Year 5 is 1991 to 1992, Year 6 is 1992 to 1993

Narragansett Bay studies Anchoa sp. was the numerically dominant species, with Tautogolabrus adpersus and Tautoga onitis among the top 5 most abundant species. Pleuronectes americanus, however, appears to be less abundant in Buzzards Bay than in Narragansett Bay. This may be due to our processing of mid-bay samples only during the middle $4 \mathrm{yr}$ of the Buzzards Bay study. Another notable difference between Buzzards Bay and Narragansett Bay (more so in the 1989 to 1990 study of Keller et al. 1999) was the small number of Ammodytes sp. larvae collected in Narragansett Bay. In Cape Cod Bay, Ammodytes sp. were the most numerous larvae (Scherer 1984), and in Buzzards Bay ranked second (1976 to 1979, Collings et al. 1981) and fourth (1987 to 1993, present study) in abundance. In Narragansett Bay, Ammodytes sp. ranked 6th in 1972 to 1973 (Bourne \& Govoni 1988) and 12th or more during the Keller et al. (1999) study. Ammodytes sp. are known to undergo large population fluctuations, with a decrease in numbers hypothesized to be a result of an increase in the populations of herring and mackerel (Sherman et al. 1981). Since Ammodytes americanus is known to inhabit coastal bays and estuaries from Delaware to Labrador (Nizinski et al. 1990), localized populations may fluctuate independently.

Average annual densities (the mean density of larvae from all the samples in which they occurred) were calculated for the 4 most abundant species collected during the $6 \mathrm{yr}$ of this study at Stns 4,5 and 6, and $95 \%$ confidence intervals were assigned (Fig. 9). Overlapping confidence intervals for Tautoga onitis, Tautogolabrus adspersus and Anchoa sp. suggest that there were no significant changes in abundance over the 6 yr. For Ammodytes sp., the confidence interval for Year 1 shows no overlap with Years 3 and 5, suggesting a more variable annual spawning cycle, which may also be evidenced by seemingly low catches of these larvae in Narragansett Bay in 1989 to 1990. Collings et al. (1981) sampled ichthyoplankton in upper Buzzards Bay, the Cape Cod Canal and Cape Cod Bay from 1976 to 1979, beginning a decade before the present study. Comparison of species lists generated by the 2 studies suggests that there have been no major shifts in species composition, and recorded maximum densities of larvae were generally similar (Table 3). The number of species found at any one station varied from year to year. Usually this variation was caused by a few specimens of uncommon species.

Results of ichthyoplankton studies are highly dependent upon sampling protocols. Gear evasion and clogging can occur with small mesh nets, making samples seem sparse or skewing the length distributions of the captured larvae (Gartz et al. 1999). Conversely, nets with larger mesh may extrude smaller or thinner larvae, possibly undersampling or biasing the average length of some species (Colton et al. 1980, Hettler \& Chester 1990). The deployment of 2 different nets, one immediately after the other, allowed for catch comparison and assessment of any differential avoidance or extrusion. 
Collection of significantly smaller sizes of anchovy larvae in the $0.102 \mathrm{~mm}$ mesh net suggests that small larvae might have been extruded through the $0.202 \mathrm{~mm}$ mesh net. Anchovies were the likeliest candidates for extrusion since they were the smallest of all the larvae collected, hatching at only 1.8 to $2.7 \mathrm{~mm}$ total length, as well as being long and thin. Even though cunner and tautog larvae hatch at only 2.0 to $2.2 \mathrm{~mm}$ (Fahay 1983), since they are stouter bodied, they would be less likely to be forced through a mesh size of $0.202 \mathrm{~mm}$. Ammodytes sp., the fourth taxon tested, is a cold water spawner and hatches at about $4 \mathrm{~mm}$. Although Ammodytes sp. larvae also have a long narrow shape, their larger mean size $(10.5 \mathrm{~mm})$ may not have allowed them to pass through $0.202 \mathrm{~mm}$ mesh, yet may have aided them in evading the smaller mouthed net, especially if its ichthyoplankton sampling efficiency was reduced due to drag due to collection of abundant zooplankton (Tranter \& Smith 1968, Colton et al. 1980). Although the nets used in this study were made of mesh small enough to theoretically eliminate extrusion, the $0.202 \mathrm{~mm}$ mesh net may have allowed some of the smallest anchovy larvae to pass through. This is supported by the fact that our peak density of Anchoa sp. larvae was $38 \mathrm{~m}^{-3}$ with the $0.102 \mathrm{~mm}$ mesh, compared to peak anchovy larvae densities of only $7.0 \mathrm{~m}^{-3}$ with a $0.505 \mathrm{~mm}$ mesh in the study of Collings et al. (1981) in Buzzards Bay, $15.6 \mathrm{~m}^{-3}$ in the study of Monteleone (1992) in Great South Bay, New York, and $26.5 \mathrm{~m}^{-3}$ found by Keller et al. (1999) in Narragansett Bay, Rhode Island. There may be a tradeoff in switching to a smaller mesh net to avoid extrusion of small larvae, because the more water filtered through a coarser mesh net, the greater the chance of capturing larvae present in low numbers. This was demonstrated by the higher number of species taken per station with the larger (0.202 mm mesh) net (Fig. 8) over the full year when all 8 stations were sampled with both nets.

In summary, Buzzards Bay appears to have a larval fish assemblage different from adjacent areas of Narragansett Bay and Cape Cod Bay. This hybrid assemblage supports the notion that Buzzards Bay is in a boundary area, and that Cape Cod is a biogeographic boundary. A recurrent annual pattern of spawning was apparent, with large summer peaks of species from pelagic eggs, and smaller winter peaks of species from demersal eggs. No adverse anthropogenic effects on distributions of fish larvae were apparent, and in fact, fish larvae were most abundant at the most polluted station over the New Bedford subsurface sewage outfall. While protocols and nets used in this study were designed primarily to sample zooplankton, they also appear to capture broad-scale patterns of ichthyoplankton. The 2 types of nets used in this study did not catch significantly different numbers of fish larvae $\mathrm{m}^{-3}$, but did collect significantly different sizes and diversity of larvae, in that the $0.102 \mathrm{~mm}$ mesh net caught significantly smaller Anchoa sp. larvae, whereas the larger diameter $0.202 \mathrm{~mm}$ mesh net collected significantly more species of larvae.

Acknowledgements. We appreciate the shipboard assistance of all participants in the Buzzards Bay time-series study, particularly K. R. Boissonneault Cellineri, D. G. Borkman, D. A. Gauthier, W. Lima, J. A. Lincoln, M. O'Brien Lyons, J. O. Hill, R. H. Pierce, C. A. Sassman Heustis, and Captains J. Gage and R. Rock. Funding was provided by the Massachusetts Department of Environmental Protection.

\section{LITERATURE CITED}

Anraku M (1964) Influence of the Cape Cod Canal on the hydrography and on the copepods in Buzzards Bay and Cape Cod Bay, Massachusetts. I. Hydrography and distribution of copepods. Limnol Oceanogr 9:46-60

Azarovitz TR, Grosslein MD (1987) Fishes and squids. In: Backus RH, Bourne DW (eds) Georges Bank. MIT Press, Cambridge, MA, p 315-346

Borkman DG, Turner JT (1993) Plankton studies in Buzzards Bay, Massachusetts, USA. II. Nutrients, chlorophyll a and phaeopigments, 1987 to 1990. Mar Ecol Prog Ser 100:27-34

Bourne DW, Govoni JJ (1988) Distribution of fish eggs and larvae and patterns of water circulation in Narragansett Bay, 1972-1973. Am Fish Soc Symp 3:132-148

Chenoweth SB (1973) Fish larvae of the estuaries and coast of central Maine. Fish Bull US 71:105-113

Collings WS, Cooper-Sheehan CC, Hughes SC, Buckley JL (1981) The effects of power generation on some of the living marine resources of the Cape Cod Canal and approaches. Massachusetts Department of Fisheries, Wildlife \& Recreational Vehicles, Division of Marine Fisheries, Boston, MA

Colton JB Jr, Green JR, Byron RR, Frisella JL (1980) Bongo net retention rates as effected by towing speed and mesh size. Can J Fish Aquat Sci 37:606-623

Crestin DS (1973) Some aspects of the biology of adults and early life stages of the rainbow smelt, Osmerus mordax (Mitchell), from the Weweantic estuary, WarehamMarion, Massachusetts. MSc thesis, University of Massachusetts, Amherst, MA

de Lafontaine Y (1990) Distribution and abundance of ichthyoplankton in the Manicouagan River Estuary, a tributary of the lower St. Lawrence. Estuaries 13:43-50

Doyle MJ, Morse WW, Kendall AW Jr (1993) A comparison of larval fish assemblages in the temperate zone of the northeast Pacific and northwest Atlantic Oceans. Bull Mar Sci $53: 588-644$

Ekman S (1953) Zoogeography of the sea. Sidgewick \& Jackson, London

Fahay MP (1983) Guide to the early stages of marine fishes occurring in the western North Atlantic Ocean, Cape Hatteras to the southern Scotian Shelf. J Northwest Atl Fish Sci 4:1-423

Gartz RG, Miller LW, Fujimura RW, Smith PE (1999) Measurement of larval striped bass (Morone saxatilis) net avoidance using evasion radius estimation to improve estimates of abundance and mortality. J Plankton Res 21: 561-580 
Govoni JJ (1973) The distribution of some marine fish eggs and larvae in the Acushnet and Westport River estuarine systems, Massachusetts. MSc thesis, Southeastern Massachusetts University, Dartmouth, MA

Herman SS (1963) Planktonic fish eggs and larvae of Narragansett Bay. Limnol Oceanogr 8:103-109

Hettler WF Jr, Chester AJ (1990) Temporal distribution of ichthyoplankton near Beaufort Inlet, North Carolina. Mar Ecol Prog Ser 68:157-168

Keller AA, Klein-MacPhee G, Burns JS (1999) Abundance and distribution of ichthyoplankton in Narragansett Bay, Rhode Island, 1989-1990. Estuaries 22:149-163

Lebida R (1969) The seasonal abundance and distribution of eggs, larvae and juvenile fishes in the Weweantic River estuary, Massachusetts, 1966. MSc thesis, University of Massachusetts, Amherst, MA

Lux FE, Wheeler CL (1992) Larval and juvenile fishes caught in a neuston survey of Buzzards Bay, Massachusetts in 1979. Northeast Fisheries Center Reference Document 92-09. NOAA/NMFS, Woods Hole, MA

Merriman D, Sclar RD (1952) Hydrographic and biological studies of Block Island Sound. The pelagic fish eggs and larvae of Block Island Sound. Bull Bingham Oceanogr Collect 13(3):165-219

Monteleone DW (1992) Seasonality and abundance of ichthyoplankton in Great South Bay, New York. Estuaries 15:230-238

Monteleone DM, Peterson WT, Williams GC (1987) Interannual fluctuations in the density of sand lance, Ammodytes americanus, larvae in Long Island Sound, 1951-1983. Estuaries 10:246-254

Nizinski MS, Collette BB, Washington BB (1990) Separation of two species of sand lances, Ammodytes americanus and A. dubius, in the western North Atlantic. Fish Bull US 88: 241-255

NOAA/EPA (National Oceanic and Atmospheric Administration/Environmental Protection Agency) (1989) Susceptibility of east coast estuaries to nutrient discharges: Passamaquoddy Bay to Chesapeake Bay. Strategic assessment of near coastal waters, summary report. US National Oceanic and Atmospheric Administration/US Environmental Protection Agency, Washington, DC

Olney JE (1983) Eggs and early larvae of the bay anchovy, Anchoa mitchelli, and the weakfish, Cynoscion regalis, in lower Chesapeake Bay with notes on associated ichthyoplankton. Estuaries 6:20-35

Editorial responsibility: Kenneth Sherman (Contributing Editor), Narragansett, Rhode Island, USA
Olney JE, Boehlert GW (1988). Nearshore ichthyoplankton associated with seagrass beds in the lower Chesapeake Bay. Mar Ecol Prog Ser 45:33-43

Pearcy WG, Richards SW (1962) Distribution and ecology of fishes of the Mystic River estuary, Connecticut. Ecology 43:248-259

Pierce RW, Turner JT (1994a) Plankton studies in Buzzards Bay, Massachusetts, USA. III. Dinoflagellates, 1987 to 1988. Mar Ecol Prog Ser 112:225-234

Pierce RW, Turner JT (1994b) Plankton studies in Buzzards Bay, Massachusetts, USA. IV. Tintinnids, 1987 to 1988. Mar Ecol Prog Ser 112:235-240

Powles H, Auger F, FitzGerald GJ (1984) Nearshore ichthyoplankton of a north temperate estuary. Can J Fish Aquat Sci 41:1653-1663

Richards SW (1959) Pelagic fish eggs and larvae of Long Island Sound. Bull Bingham Oceanogr Collect 17(1): 95-124

Scherer MD (1984) The ichthyoplankton of Cape Cod Bay. Lecture Notes on Coastal and Estuarine Studies, Vol 11. Observations on the ecology and biology of western Cape Cod Bay, Massachusetts. Springer Verlag, Berlin, p 151-190

Sherman K, Jones C, Sullivan L, Smith W, Berrien P, Ejysmont L (1981) Congruent shifts in sand eel abundance in western and eastern North Atlantic ecosystems. Nature 291:486-489

Stolgitis JA (1970) Aspects of the biology of the tautog from the Weweantic estuary. MSc thesis, University of Massachusetts, Amherst, MA

Theilacker GH (1980) Changes in body measurements of larval northern anchovy, Engraulis mordax, and other fishes due to handling and preservation. Fish Bull US 78: 685-692

Tranter DJ, Smith PE (1968) Filtration performance. In: Tranter DJ, Fraser JH (eds) Zooplankton sampling, UNESCO monographs on oceanographic methodology. UNESCO, Paris, p 27-56

Turner JT, Borkman DG (1993) Plankton studies in Buzzards Bay, Massachusetts, USA. I. Hydrography and bacterioplankton, 1987 to 1990. Mar Ecol Prog Ser 100: $17-26$

Wheatland SB (1956) Oceanography of Long Island Sound, 1952-1954. VII. Pelagic fish eggs and larvae. Bull Bingham Oceanogr Collect 15:234-314

Submitted: October 30, 1997; Accepted: March 19, 2001

Proofs received from author(s): November 25, 2001 